Kinga Czerwińska

ORCID: https://orcid.org/0000-0001-8595-3166

Uniwersytet Śląski w Katowicach

Instytut Nauk o Kulturze

\title{
Ostatni taki „Judosz”'. \\ Uwagi o konstruowaniu i dekonstruowaniu dziedzictwa kulturowego w kontekście tożsamości mieszkańców Skoczowa
}

\author{
The last such "Judosh". \\ Remarks on constructing and deconstructing of cultural \\ heritage in the context of the identity of the residents \\ of Skoczów
}

\begin{abstract}
One of the key factors that shape the profile of the local culture is the value-determining attitude towards one's own cultural heritage, which is grounded over the period of several generations. Heritage, and thus defining the past, becomes the ground for seeking a common social and cultural identity that ultimately turns into a platform for activity based on social bonds. The manifestation of these bonds is expressed by the local community integration coefficient. An intriguing aspect of it is a situation where the value of cultural heritage is undermined either by the community members or by certain external factors. Defence mechanisms vary significantly whilst the consequences may destabilise the sense of community or, on the contrary, strengthen it. Theoretical theses of the article are based on empirical research on the origins of the "Judosh" parade, which constitutes one of the identity determinants of the residents of Skoczów. An unsuccessful
\end{abstract}

1 Tytuł zaczerpnięty z tekstu R. Orawskiego, opublikowanego w Kalendarzu Mitośników Skoczowa 2000 (Orawski 2000). The title quotation is from R. Orawski's text published in Kalendarz Mitośników Skoczowa 2000 . 
attempt to enter this custom in the UNESCO National List of Intangible Cultural Heritage triggered a wave of confusion among the residents and, as a consequence, gave rise to reflection on the vitality of this custom as well as to attempts at deconstructing it.

Key words: cultural heritage, identity, invention of tradition, performativity of heritage

Jednym z głównych czynników kształtujących profil kultury lokalnej jest ugruntowany w ciągu wielu pokoleń, wartościujący stosunek do własnego dziedzictwa kulturowego. Dziedzictwo, a co za tym idzie definiowanie przeszłości, daje płaszczyznę poszukiwania wspólnej tożsamości społecznej i kulturowej, która w rezultacie staje się platformą aktywności opartej na więziach społecznych. Ich manifestowanie wyraża współczynnik integracji wspólnoty lokalnej. Interesującym zwrotem jest sytuacja, w której wartość dziedzictwa kulturowego zostaje podważona albo przez członków wspólnoty, albo przez bodźce z zewnętrz. Mechanizmy obronne mają różny charakter, a konsekwencje mogą zdestabilizować wspólnotowość społeczności lub, przeciwnie, mogą ją wzmocnić.

Tezy teoretyczne artykułu oparte są na badaniach empirycznych nad pochodem z Judoszem, który stanowi jeden z wyznaczników tożsamościowych mieszkańców Skoczowa. Zakończona fiaskiem próba wpisania zwyczaju na Krajową listę niematerialnego dziedzictwa kulturowego UNESCO wywołała konsternację wśród inicjatorów wpisu, a w konsekwencji refleksję nad żywotnością tej praktyki i próbę jej dekonstruowania.

Słowa kluczowe: dziedzictwo kulturowe, tożsamość, tradycja wynaleziona, performatywność dziedzictwa

Odebrano / Received: 28.01.2021

Zaakceptowano / Accepted: 05.10.2021

\section{Wprowadzenie}

Pojęcie tożsamości jest „niezbędnym, a może nawet zasadniczym narzędziem pojęciowym w analizie sytuacji człowieka w społeczeństwie współczesnym i próbach wyjaśnienia bądź zrozumienia kluczowych fenomenów społecznych naszych czasów" (Bokszański 1989: 6). Pytanie o tożsamość wyrasta z poczucia destabilizacji istnienia we współczesnej rzeczywistości, z niedookreślenia, jakie w sobie zawiera oraz niepewności i niedostateczności wszelkich form, jakie tożsamość przybiera. Jak wskazuje Zygmunt Bauman, tożsamości nie dostaje się ani w prezencie, ani z wyroku bezapelacyjnego, jest ona czymś, co się konstruuje i co można formować na różne sposoby. W konsekwencji oznacza to, że nadawanie kształtu tożsamości jest zadaniem do wykonania, przed którym nie ma ucieczki. Równocześnie realizacja zadania, o którym mowa, może budzić pewne obawy związane $z$ koniecznością wyboru własnej tożsamości oraz możliwością manipulowania procesem jej formowania przez instytucjonalizm czy dominujące ideologie. Legitymizacja i kształtowanie własnej identyfikacji może wywoływać pewną sprzeczność, która wynika z jednej strony, z konieczności wyboru tożsamości, a więc zdefiniowania siebie. $Z$ drugiej zaś strony, wybór ten w pewnym stopniu ogranicza 
człowieka, zamyka w ramach desygnowania tego, kim się jest, a to uderza w wolność, która jest, jak mówi Bauman, losem człowieka (Bauman 1994: 9).

Proces budowania tożsamości powstaje w oparciu o każdy rodzaj relacji zachodzących pomiędzy jednostkami i rozwija się względem poczucia przynależności do wybranej społeczności i odrębności od innych. Owa relacyjność staje się gruntem dla kształtowania identyfikacji na poziomie podmiotu i grupy, a poszukiwanie jej wyznaczników odbywa się na wielu płaszczyznach. Jednostka bowiem poszukuje „unikalności” własnej osoby, ale i poczucia podobieństwa, przynależności do określonej kategorii społecznej, w ramach aktualnie żyjącego pokolenia oraz jego przeszłości, przekonania o wspólnocie, a także ciągłości czasu i przestrzeni (Burszta 2004).

Wśród wielu płaszczyzn kształtowania się tożsamości za najważniejszą przyjmuje się płaszczyznę kulturową, historycznie uwarunkowaną oraz zachowującą istnienie i ciągłość zbiorowości. Tożsamość tę wyznaczają: „1) elementy dziedzictwa, nawet całkowicie lub częściowo zdezaktualizowane, 2) rodzaj, proporcje i ustrukturyzowanie składowych elementów danej kultury zarówno ze względu na odrębności wyróżników kulturowych, jak i na osiągnięty poziom powszechników społeczno-ekonomicznych i cywilizacyjnych wewnątrz danej kultury, 3) kontekst zewnętrzny równorzędnych czy nierównorzędnych kontaktów $\mathrm{z}$ innymi kulturami, występujących $\mathrm{w}$ różnym natężeniu w przeszłości i teraźniejszości” (Kwaśniewski 1987: 341-352). Dziedzictwo kulturowe staje się tu swoistym rdzeniem, wokół którego kształtuje się tożsamość. Stopień jego zachowania, formy jego przekazu, jak i recepcja treści wyraża stosunek do własnej kultury, a co za tym idzie - intensywność identyfikacji jednostki lub grupy. Świadomość tego, kim się jest, wiąże się zatem z poczuciem przynależności do własnej społeczności, z identyfikowaniem się z jej specyficzną kulturą, wspólną historią, z określonym terytorium, które się razem zamieszkuje (Wieruszewska 1989: 310).

Dziedzictwo kulturowe - materialne czy niematerialne zawsze jest dziedzictwem czyimś, w procesie dziedziczenia trafia do osób, które mogą je przyjąć lub odrzucić. Nie ma bowiem dziedzictwa bez świadomości jego istnienia i działan, wynikających z tego faktu. Proces dziedziczenia to przecież selektywna recepcja, podczas której spadkobiercy konsumują to, co stanowi w ich opinii wartość, podczas gdy inne elementy deprecjonuje, odrzuca. Trudno bowiem wyobrazić sobie, by wszystkie dobra powstałe jako dorobek generacji mogły zostać skumulowane i przekazywane kolejnym pokoleniom. Dlatego proces dziedziczenia rozumiem jako medium międzypokoleniowej komunikacji, za pośrednictwem którego formuje się ład społeczny i wyobrażenia o świecie, a także kształtuje się tożsamości indywidualną i grupową (Smith 2016). Dziedzictwo w ujęciu podmiotowym nie należy zatem do porządku przeszłości, jak zwyczajowo utarło się je traktować, ale do teraźniejszości i przyszłości. Pisze o tym Marcin Lubaś: „Dziedzictwo kulturowe należy - co za tym idzie - uznać za działania i zabiegi o charakterze mnemonicznym - wysiłek ciągłego przypominania jednym przez drugich 
o tym, co należy za wszelką cenę ocalić od zapomnienia i zniszczenia $\mathrm{z}$ uwagi na jego nieprzemijającą wartość dla pewnej części lub całości ludzkości” (Lubaś 2017: 17).

Konstatacja ta przenosi nasze zainteresowanie na proces wytwarzania dziedzictwa, w którym nie tylko odtwarza się fragmenty przeszłości, ale również nadaje mu wartość. W konsekwencji podejmuje się kroki, by dziedzictwo przekazać, zachować, bronić i chronić. Efektem tych działań jest szczególny sposób produkcji kulturowej, w którym odwołując się do przeszłości - tworzy się coś nowego (Kirshenblatt-Gimblett 1998).

Kryją się za tymi działaniami instytucje o bardzo różnym szczeblu i zakresie zadań, których cel jawi się nie tylko jako wypełnianie obowiązków związanych z zachowaniem dziedzictwa, m.in. archiwizacja czy upowszechnianie komplementarnej wiedzy. Praca ta często nosi znamiona misji, której przyświeca chęć ocalenia spuścizny przeszłości i przekazania jej kolejnym pokoleniom, ale i coś więcej - kreacja wspólnoty opartej o więzi istniejące $w$ ujęciu synchronicznym i diachronicznym. Więzi te powstają na bazie przypisywanym dziedzictwu cechom, takim jak: trwałość, unikalność, autentyczność, i stanowią istotny czynnik wspierania kapitału społecznego i regulacji sfery tożsamości kulturowych czy narodowych. Stanowisko to, bliskie badaczom kulturowej rzeczywistości wielu dziedzin nauki, można określić konstruktywistycznym, a jego podstawy zostały ugruntowane przez brytyjskich historyków społecznych - Erica Hobsbawma i Terence'a Rangera (2008).

Przyjmując, że w obliczu zmian będących efektem intensywnego procesu uprzemysłowienia zostały przerwane międzypokoleniowe więzi oparte na przekazie kulturowych treści, a obcowanie $\mathrm{z}$ dziedzictwem jest naturalnym procesem wynikającym $\mathrm{z}$ zaspokojenia ludzkich potrzeb zachowania ciągłości z przeszłością, ciągłość tę można przywrócić. „Wytwarzanie” dziedzictwa staje się w tym wypadku narzędziem, które służy legitymizacji władzy oraz podtrzymywaniu, korzystnych dla elit rządzących lub innych grup uprzywilejowanych, stosunków społecznych (Fog Olwing 1999: 370-388).

Niemniej istotny wkład $\mathrm{w}$ procesie konstruowania dziedzictwa mają również, a może należałoby podkreślić, że przede wszystkim, jego depozytariusze. Dziedzictwo stanowi źródło wartości dla pewnej, określonej wspólnoty, która jest zarazem zobowiązana do zarządzania powierzonymi jej zasobami. Stopień rangi, jaką nadaje dziedzictwu zbiorowość oraz sposób jego postrzegania, warunkuje powodzenie wszelkich działań o charakterze instytucjonalnym. Każde pokolenie, według własnych potrzeb, dokonuje selekcji elementów dziedzictwa, czyniąc coraz to nowe jego elementy przedmiotem wartościowania, przy równoczesnym porzucaniu innych. Wyselekcjonowanym zasobom przypisywać należy raczej otwarty rezerwuar interpretacji niż prawdę historyczną.

Nawiązania do dziedzictwa, które służy do wzmocnienia własnej tożsamości na płaszczyźnie regionalnej lub narodowej obserwujemy współcześnie w wielu miejscach świata. Jak wykazują badania, popularność tego mechanizmu w konstruowaniu teraźniejszości jest powszechna i ciągle wzrasta (Lubaś 2008: 33-69). Współczesna obecność trendów afirmujących wybrane aspekty przeszłości, można tłumaczyć intensywnymi 
procesami globalizacyjnymi, które osłabiają obowiązujące dotychczas praktyki regulujące życie codzienne. Jan Kajfosz podkreśla, że im szybciej zmienia się świat, tym bardziej szukamy czegoś, co da nam oparcie, zaczepienie w stałości, a stałość taka kryje się w tradycji (oraz, w moim przekonaniu, w dziedzictwie). Potrzeba ulokowania się w znanej rzeczywistości, którą Kajfosz nazywa kosmosem, jest alternatywą dla chaosu, który właściwy jest dla współczesnego świata (Kajfosz 2009: 83).

Instytucjonalne mechanizmy dziedziczenia to świadome odwoływanie się do przeszłości nastawione na konkretne cele. Dzięki zastosowaniu cyklicznie powtarzanych, sformalizowanych i zrytualizowanych praktyk, odbieranych jako tradycyjne (w domyśle - uświęcone ciągłością trwania, wspólnotą pokoleń) można konstruować narzędzie kontroli danej grupy społecznej. Narzędzie to jest wykorzystywane na wiele sposobów, zarówno do władzy politycznej, jak i celów merkantylnych, bardziej lub mniej refleksyjnie, zawsze jednak towarzyszy mu różnie pojęte dobro interesu grupy. Bez względu na efekt podejmowanych działań, istotny jest przy tym fakt, że w procesie percepcji przetworzonych, „przepakowanych” na nowo treści, dziedzictwo jest nieodłącznym składnikiem budowania tożsamości. „Wydestylowany” w tych działaniach produkt przekłada się bezpośrednio na odbiorców.

\section{O wodzeniu skoczowskiego Judosza ${ }^{2}$, czyli konstruowanie i dekonstruowanie dziedzictwa}

Praktyki obrzędowe i zwyczajowe celebrowane cyklicznie stanowią jeden z głównych przejawów dziedzictwa kulturowego. Ich trwanie i ciągłość są ważnym ogniwem spajającym wspólnotę na poziomie lokalnym i narodowym, a bywa, że łączą społeczność ponad jakimikolwiek granicami. Trwanie postrzegane bywa za czynnik kluczowy w zapewnieniu spójności grupy, czego dowód dostarcza rytualne odtwarzanie praktyk, często bez znajomości ich religijnego czy kulturowego kontekstu. Znaczenie symboliki przestaje być imperatywem działania, a stają się nim maksymy: zawsze się tak robiło, dziadkowie tak robili, trzeba robić, jak dawniej. Tego rodzaju deklaracje wskazują na potrzebę „ukorzenienia” siebie w konkretnym miejscu i czasie. Dlatego wykorzystywane są często do budowania identyfikacji grupy jako element więziotwórczy i stają się ważnym filarem $\mathrm{w}$ prowadzeniu polityki lokalnej. Tak też dzieje się w przypadku wodzenia Judosza, zwyczaju, który zajmuje ważne miejsce w procesie kształtowania tożsamości mieszkańców Skoczowa.

\footnotetext{
2 Materiał wywołany kolekcjonowano podczas badań etnograficznych w latach 1995-2020, wykorzystując obserwację uczestniczącą i wywiad. Badania i refleksje nad tą praktyką zwyczajową towarzyszą mi od początków mojej aktywności badawczej, a rozpoczęły się już w okresie studiów etnograficznych. Jestem skoczowianką i czułam się zobligowana do prowadzania badań nad Judoszem, zarówno jako badaczka, jak i członkini społeczności lokalnej. Przyjęta przeze mnie postawa metodologiczna to autoetnografia, którą rozumiem za Carolyn Ellis, jako praktykę badawczą i pisarską, łączącą wątki autobiograficzne i osobiste badacza, z jego refleksją na temat zjawisk kulturowych i społecznych (Ellis 2003).
} 
Wśród wielu ciągle praktykowanych zwyczajów i obrzędów o proweniencji ludowej, będących nieodłącznym elementem tradycji i historii Skoczowa, miasta leżącego na Śląsku Cieszyńskim, są te należące do cyklu dorocznego, związane z Wielkanocą. Wielość praktyk odtwarzanych w tym czasie zwraca uwagę swoim bogactwem, część $\mathrm{z}$ nich osadzona jest $\mathrm{w}$ obrzędowości regionu, inne mają charakter uniwersalny, powszechny, ale występują tu i takie, które trudno znaleźć na innych terenach.

Do kulminacyjnych praktyk tego okresu należy pochód z Judaszem, nazywany tu wodzenie Judosza lub chodzenie z Judoszem, znany niegdyś w licznych miejscowościach regionu i poza nim (m.in. Ogrodowska 2004; Tokarska-Bakir 2004: 73-94). Zwyczaj ten odbywał się w Wielkim Tygodniu, zwykle po zawieszeniu dzwonów od Wielkiego Czwartku do Wielkiej Soboty, a polegał na oprowadzaniu kukły symbolizującej Judasza w granicach danej miejscowości w asyście mieszkańców (najczęściej dzieci). Pochodowi towarzyszyły dźwięki kołatek, a jego finał sprowadzał się do powieszenia kukły, jej spalenia albo zatopienia. W źródłach etnograficznych zwyczaj przedstawia się jako obecny w wielu miejscowościach Śląska Cieszyńskiego i żywotny w latach 60. dwudziestego stulecia, aczkolwiek stopniowo zanikający. $Z$ materiałów tych wyłania się wodzenie Judosza jako praktyka dawna, powszechna w regionie i kultywowana w wielu miejscowych wariantach. Oprócz wspólnych dla tego zwyczaju elementów, takich jak: figura Judasza - kukła ze słomy lub gałganów, przemarsz, asysta dzieci, przeważnie chłopców w wieku 8-12 lat, rozbrzmiewający dźwięk kołatek, występowały lokalne warianty, które dotyczyły finałowych czynności pochodu: palenia kukły, wieszania lub jej topienia, w kilku przypadkach pojawiał się również wątek opalania w ogniu gałązek leszczyny, a następnie wykonywanie $z$ nich krzyżyków. W drugim dniu Wielkanocy, zanoszono je na pola i wsadzano do ziemi w celu ochrony przed szkodnikami (Broda 1972). Tam, gdzie nie przygotowywano kukły, tam ceremonię święcenia ognia rozpalanego przed kościołem w Wielką Sobotę nazywano paleniem Judasza (Kwaśniewicz 1984: 181; Pośpiech 1987: 172-173).

Wśród licznych miejscowości Śląska Cieszyńskiego wodzenie Judosza praktykowano również w Skoczowie. Zwyczaj ten zachował swoją żywotność do dziś, i jak głoszą zwolennicy i inicjatorzy jego odtwarzania, wpisuje się „nierozerwalnie” w historię miasta. Choć trudno jednoznacznie stwierdzić, kiedy Judosz pojawił się w skoczowskim grodzie, to wersje upowszechniane przez miejscowych regionalistów odsyłają nas do XVIII wieku, kiedy miał przywędrować tu z Moraw. Nieliczne głosy chciałyby upatrywać śladów tej praktyki w pomrokach średniowiecza (Orawski 2008: 1), niemniej wzmianki udokumentowane przez historyków i lokalnych miłośników miasta, potwierdzają, że pochód ze słomianą kukłą powszechnie praktykowany był w mieście w XIX wieku. Zaś najstarsze fotografie, zgromadzone m.in. w Muzeum Śląska Cieszyńskiego, przedstawią sceny z lat 20.-30. XX wieku³. Relacje świadków, uczestników zwyczaju, sięgają

3 Najstarsze zdjęcie dokumentujące lokalny zwyczaj pochodu z Judaszem (wraz z opisem zwyczaju) pochodzi z 1908 roku ze Strumienia. W przypadku opisywanej praktyki, Judaszowi (tu chłopczyk z doklejoną 
okresu przed II wojną światową i stają się na powrót „żywe” po 1946 roku, czyli przerwie wymuszonej okupacją, kiedy ta praktyka została zakazana jako przejaw zabobonów i ludowych przesądów.

Z dawnych materiałów etnograficznych wyłania się skoczowskie chodzenie z Judoszem jako praktyka towarzysząca obchodom całego Wielkiego Tygodnia, rozpoczynająca się już w poniedziałek. Pochód odbywał się dwa razy dziennie, ruszał przy stodole farnej, na Kaplicówce, wzgórzu górującym nad miastem, a gawiedź prowadząca chochoła maszerowała uliczkami miasta, by w Wielką Sobotę wyprowadzić go poza centrum, na wzmiankowane wzgórze, i tam spalić. Inicjatorami wydarzenia i głównymi uczestnikami byli chłopcy, m.in. ministranci związani z kościołem pw. św. św. Piotra i Pawła, którzy nie tylko przygotowywali kukłę, ale również aranżowali całe przedsięwzięcie.

Nie udało ustalić się, kiedy zredukowano pochód do dwóch dni (piątku i soboty), ani kiedy wyznaczono obecny szlak przemarszu i miejsce spalenia Judosza. $Z$ materiałów popularyzujących praktykę upowszechnianych przez Towarzystwo Miłośników Skoczowa wynika, że stało się to „nieco później” (Orawski 2008: 8), czyli po I wojnie światowej. Coroczne chodzenie z Judoszem, jak wspominałam wcześniej, przerwała okupacja, by na powrót znaleźć się na ulicach miasta dopiero w 1946 roku. Praktykę kontynuowano do 1966 roku, by po kilkunastoletniej przerwie powrócić do niej w 1981 roku. „Zawieszenie” zwyczaju było spowodowane wystąpieniem jednego z młodych wikarych z kościoła parafialnego, który uznał ów za pogański, szkodliwy dla Kościoła, o czym przekonał także proboszcza i ten zabronił ministrantom organizowania pochodu.

Wyjątkiem od tego postanowienia stało się pojawienie słomianej kukły podczas obchodów uroczystości związanych z siedemsetleciem założenia miasta, które odbywały się w czerwcu 1967 roku. Jako charakterystyczny znak miasta osadzony w jego tradycjach i historii, Judosz kroczył w pochodzie wraz z innymi, ważnymi dla Skoczowa postaciami.

Ponowne pojawienie się Judosza nastąpiło w 1981 roku z inicjatywy Ochotniczej Straży Pożarnej, a kilka lat później, w 1985 roku w przygotowania włączyli się członkowie Towarzystwa Miłośników Skoczowa. Stopniowo zwyczaj nabierał charakteru sformalizowanego i ustrukturalizowanego, a do uczestnictwa w nim angażowano mieszkańców miasta w różnym wieku, nie tylko dzieci. Kontynuatorzy praktyki, zaabsorbowani w proces jej odtwarzania, podzielili obowiązki organizacji całego wydarzenia, które obejmują: starania o przygotowanie stroju czy rekwizytów oraz formalne

brodą) asystowała nie tylko grupa dzieci wyposażonych w kołatki, grzechotki i specjalne taczki do grzechotania, ale również diabeł - chłopiec przebrany w masce, kożuchu odwróconym podszewką ku górze, trzymający w ręce słomiane powrósła imitujące bicze. Taki korowód, prowadzony przez postaci diabła i Judasza, obchodził trzykrotnie kościół, a potem wyruszał od domu do domu, zbierając różnego rodzaju datki. Pochód kończył się powieszeniem Judasza na gałęzi, podczas którego skandowano: „Judaszu, zdradziłeś Pana Jezusa!". Zob. Materiaty (Objaśnienie ilustracji wykonanej wedtug Henryka Eisenbacha, aptekarza w Strumieniu), „Zaranie Śląskie” 1908, R. 2, z. 3, s. 137. Za: Studnicki 2017: 172). 
i administracyjne zabezpieczenie trasy, co wymaga uprzedniego uruchomienia procedur $\mathrm{w}$ celu uzyskania stosownych pozwoleń ${ }^{4}$.

Idea przewodnia chodzenia $z$ Judoszem nawiązuje do postaci ucznia Jezusa, który zdradzając swojego mistrza, wydał go na męczeńską śmierć. Ucieleśnia go słomiana kukła, wykonana z niemłóconego żyta, wysoka na 3 metry, ozdobiona kolorowymi wstążkami i naszyjnikiem z 30 srebrników, które otrzymał za zdradę. Postać tę oprowadza się po ścisłym centrum miasta, w asyście dwóch halabardników w hełmach na głowach, ubranych w ciemne peleryny, którzy prowadzą go, podtrzymując za słomiane ramiona. Za nimi podążają dzieci z kołatkami, skandując „kle, kle, kle, kle, kle”. W narracji o tym wydarzeniu przyjmuje się, że słomiany chochoł symbolizuje zło, zaś klekotki wyganiają je z ulic i domów (przestrzeni miasta) oraz symbolizują trzęsienie ziemi, jakie wystąpiło na Golgocie, gdy Chrystus umierał na krzyżu. Pochód, który zamykają mieszkańcy i turyści przemierza miasto w Wielki Piątek i Wielką Sobotę. Dokładnie w południe słomiany Judosz wychodzi ze strażnicy OSP i idzie na rynek pod ratusz, gdzie trzykrotnie kłania się władzom miejskim ${ }^{5}$. Potem podąża ulicami miasta, by na koniec wrócić do parku za strażnicą, gdzie w Wielką Sobotę przy dźwięku klekotek płonie. Ogień niszczy kukłę, a wraz z nią ginie zło, które mogłoby szkodzić miastu i jego mieszkańcom. W rzeczywistości jednak, od kilku już lat podpala się atrapę ustawioną z bali siana, a strój przechowuje się do następnych odsłon tego zwyczaju.

Nowe realia społeczno-kulturowe (po 1989 roku), uruchomiły konieczność zwiększenia starań o popularyzowanie tej skoczowskiej praktyki oraz jej upowszechnianie jako istotnego elementu strategii lokalnej polityki. Wśród wielu materiałów promocyjnych, w tym publikacji, które ukazały się staraniem lokalnych animatorów życia kulturalnego Skoczowa i regionalistów, w 2006 roku powstał film dokumentalny pt. Skoczorwski Judasz. Obyczaje wielkanocne w Skoczowie na Śląsu Cieszyńskim. Projekt został wsparty finansowo przez samorząd województwa śląskiego oraz Miejski Dom Kultury w Skoczowie. Kanwą scenariusza była prezentacja pochodu z Judoszem, który został osadzony w kontekście innych, miejscowych praktyk wielkanocnych, tj. wielkoczwartkowego obmywania się w nurcie Wisły czy przygotowania i degustacji tatarczówki, które odbywają się w Wielki Piątek. Zwyczaje wskazane w filmie jako spójny cykl praktyk

${ }_{4}$ Zgodnie z przepisami najpóźniej 30 dni przed Wielkim Piątkiem należy przygotować i złożyć wniosek o wykorzystanie pasa drogi w sposób szczególny do Starostwa Powiatowego w Cieszynie, Wojewódzkiej Komendy Policji w Katowicach oraz Śląsko-Małopolskiego Oddziału Straży Granicznej w Raciborzu. Służby te wraz ze strażakami z miejskiej jednostki OSP są odpowiedzialne za zabezpieczenie pochodu. Dodatkowo, co roku, strażacy angażują się w sam przebieg pochodu - jeden z nich ubiera się w strój Judosza, a dwóch innych odgrywa role halabardników wiodących go ulicami miasta. Ponadto dbają o odpowiednie przechowywanie i ewentualną naprawę stroju kukły oraz około 100 kołatek, których używają uczestnicy w czasie pochodu.

5 Zwyczajowo pochód po drodze zatrzymywał się przed plebanią, gdzie kłaniał się proboszczowi. O powodach zmiany, piszę w dalszej części tekstu. 
wielkotygodniowych były wówczas wśród mieszkańców rozpoznawalne i kultywowane w niewielkim stopniu, z wyjątkiem pochodu z Judoszem.

Rytualne obmywanie nóg, które w kościele katolickim odbywa się podczas nabożeństwa wielkoczwartkowego otwiera skoczowski cykl praktyk Wielkiego Tygodnia. Wśród lokalnej społeczności praktykuje się obmywanie twarzy, rąk czy nóg w rwącej rzece (głównie w Wiśle, nad którą ulokowane jest miasto). Woda ta, w owym czasie zyskuje szczególną moc uzdrawiania. Osoby spotykają się zwykle w małych grupkach, o północy Wielkiego Czwartku lub bardzo wcześnie rano w Wielki Piątek, by wspólnie wyruszyć w kierunku rzeki. Cała praktyka powinna odbywać się w absolutnej ciszy.

Kolejny wskazany w filmie zwyczaj dotyczy spożywania małego kieliszka specjalnej wódki - tatarczórwki, którą pito w Wielki Piątek, na pamiątkę Męki Pańskiej. Ta niezwykle gorzka w smaku nalewka na bazie korzenia tataraku ma nawiązywać do octu z żółcią, którą podawano konającemu Jezusowi na krzyżu. Jej spożywanie, co wynikało z przekonania mieszkańców, miało również zapewnić zdrowie w nadchodzącym roku, a jej właściwości pomagać na niemal wszystkie dolegliwości od bólu zęba po kłopoty z potencją.

W 2006 roku staraniem TMS nalewkę przygotowywaną przez miejscowych koneserów dopuszczono do sprzedaży, a w 2008 roku wpisano na sygnowaną przez Ministerstwo Rolnictwa i Rozwoju Wsi Listę produktów tradycyjnych w kategorii napoje. Pozytywne rozstrzygnięcia, uznające tatarczórwkę za ważny dla polityki regionalnej element, spowodowały, że jej degustację włączono w obchody wodzenia z Judoszem. Po zakończeniu pochodu starsi jego uczestnicy udają się do biura promocji i informacji miasta - ARTadresu, gdzie odbywa się smakowanie. Praktyka ta, jak argumentują organizatorzy, ma na celu zintegrować mieszkańców i stać się czasem celebracji wspólnych tradycji ${ }^{6}$.

W podobnym tonie, wzmacniania figury Judosza w wytwarzaniu tożsamości miejsca i jego mieszkańców, zainicjowano pieczenie pierników w kształcie imitującym kukłę. Ciastka te przygotowuje jedna z najstarszych cukierni w Skoczowie - U Dusia, w tym wypadku odwołując się do dziedzictwa wyrobów piernikarskich, a szerzej tradycji rzemieślniczych, które od średniowiecza rozwijały się w grodzie nad Wisłą. Pierniki Judosze, można kupić nie tylko w okresie wielkanocnym, ale w ciągu całego roku, podobnie jak tatarczówkę. Stały się one lokalnym gadżetem - pamiątką dla odwiedzających miasto.

Okres Triduum Paschalnego zamykają praktyki kultywowane w Wielką Sobotę. Do wiodących tego dnia zwyczajów należy odwiedzanie Bożego Grobu, często połączone ze święceniem pokarmów. W kościele parafialnym w Skoczowie Boży Grób ma specjalną oprawę w postaci straży pełnionej przez członków miejscowej OSP, którzy tę służbę pełnią $\mathrm{w}$ galowym umundurowaniu. Zaangażowanie strażaków

\footnotetext{
6 Nie wszyscy jednak pochwalają ten proceder, upatrując w nim propagowanie picia alkoholu i szerzenie alkoholizmu, zwłaszcza w czasie, kiedy chrześcijan obowiązuje ścisły post i umartwianie się.
} 
w kultywowanie lokalnego dziedzictwa wpisuje się w historię miasta, wielokrotnie trawionego pożarami.

Wodzenie Judosza przedstawiane jako praktyka unikatowa, stała się znacząca dla zachowania tożsamości wspólnoty lokalnej skoczowian. Jej religijno-magiczny, pierwotny sens, który osadził ją w konkretnym miejscu roku obrzędowego, zatracił swe prymarne znaczenie na korzyść budowania „tradycji” wiążącej zbiorowość. Poszukiwanie autentyczności zwyczaju, jego archaiczności, osadzenie w szerszym kontekście innych, również unikalnych elementów (tj. tatarczórwka) dało lokalnym działaczom sposobność do legitymizowania wspólnotowości skoczowian, umacniania granic grupowych, budowania odrębnej tożsamości opartej na emocjonalnym stosunku do tego, co nasze. Narracja ta, wspólna dla związanych z Judoszem materiałów (publikacji promocyjnych, relacji w prasie lokalnej, filmów), tworzy dyskurs osadzony na powtarzających się wypowiedziach: o naszej, ciekawej tradycji, wyjątkowej tradycji, której zanik może spowodować, że utarci się siebie i swoja tożsamość (Studnicki 2017:193). Figura Judosza służy do wzmocnienia obrazu „małej ojczyzny”, z którą mieszkańcy mogą się identyfikować. Powoływanie się na trwałość zwyczaju, pozwala na ogniskowanie się wokół niej skoczowian jako wokół czegoś unikatowego, a to zaś umożliwia przeniesienie, ,zapożyczenie” owej wyjątkowości na społeczność, która jest depozytariuszem tego dziedzictwa. Każdy bowiem z elementów, który stanowi o specyfice miejsca, służy równocześnie mityzacji wyobrażeń o tym miejscu (o mieszkańcach) i jego wartościach. W tym kontekście, Judosz stał się istotnym elementem dyskursu lokalno-regionalnego, ulokowanego na łamach miejscowych mediów, Internetu i innych tekstów popularyzatorskich.

Emocjonalny stosunek do Judosza, czyli dziedzictwa wspólnotowego, dał się mocno zauważyć podczas wydarzeń, które miały miejsce w 2007 roku. Grupa osób związana z Ligą Polskich Rodzin wystąpiła z apelem o zaprzestanie praktykowania zwyczaju, jako godzącego w uczucia religijne miejscowych katolików i ewangelików, dla których Wielki Piątek jest szczególnie celebrowany z powagą i w ciszy. Manifest ten spotkał się z dużym poruszeniem, zarówno wśród przeciwników zwyczaju, jak i jego orędowników i kontynuatorów. Podsycany medialnie szum zaowocował polaryzacją społeczności i rozlał się poza granice miasta. W spór zaangażowani zostali nie tylko członkowie TMS czy OSP, ale również ówczesne władze miasta, Rada Miasta, środowisko księży, a społeczność dawała upust swoim emocjom na forach internetowych. Proboszcz parafii pw. św. św. Piotra i Pawła, ks. Alojzy Zuber wystosował do wiernych list, który został odczytany w Niedzielę Palmową. Zawarte treści dotyczyły przedstawienia tradycji jako pogańskiej, zakłócającej powagę Wielkiego Piątku i Soboty. Zważywszy na konotacje tego zwyczaju, chrześcijanie według proboszcza nie powinni brać w nim udziału. $Z$ punktu widzenia analizy praktyki, ważne wydaje się dodanie, że środowisko skoczowskich księży nie było w tej kwestii jednoznaczne i tak kategoryczne, jak proboszcz, który w opinii mieszkańców ugiął się pod wpływem nacisków środowisk związanych z ojcem Rydzykiem oraz z partiami wówczas rządzącymi, takimi jak PIS, LPR czy Samoobrona. Wątek ten zresztą 
zdominował konflikt wokół Judosza. Skoczowski zwyczaj, z poziomu polityki lokalnej, stał się częścią dyskursu ogólnopolskiego, rozpatrywanego w kategorii zamachu na wolność i ograniczenie swobód społeczności miasta. Uczestnicy sporu dokonywali podziału społeczeństwa na „swoich” i „obcych” - wrogów rodzimej odmienności, którzy, z pozycji władzy, chcą zdominować możliwość decydowania o własnych, indywidualnych wyborach.

W komentarzach do wydarzenia, obie strony sporu przywoływały argumenty odwołujące się do etnografii czy historii religii, by zracjonalizować zajmowane stanowiska. Klasyfikacja praktyki jako zabobonu, atak na wiarę katolicką, szerzenie pogaństwa stawiano w opozycji do takich argumentów jak: obrona cyklu obrzędowości, która w synkretyczny sposób łączy to, co religijne z pogańskim, ludowym; zamach na tradycje przodków i regionalne dziedzictwo, czy wreszcie, jako: „nieszkodliwa, nie przeszkadzająca nikomu zabawa, atrakcja dla mieszkańców i turystów; symbol Skoczowa itd. Przeciwnikom Judasza zarzucano indoktrynację ideologiczną, zamknięcie na świat $i$ inność, brak tolerancji” (Studnicki 2009: 237).

Ostatecznie konflikt zakończył się zmianą trasy pochodu, która od tego momentu omija bezpośrednio kościół parafialny oraz wykluczeniem z praktyki proboszcza, który wcześniej czekał na pochód i kłaniającego się mu Judosza. Skutkiem pośrednim całego zamieszania było zwiększenie popularności zwyczaju oraz gremialny udział w pochodzie mieszkańców Skoczowa, ale i innych, zaciekawionych tą sytuacją.

Jako zespół wciąż żywych, a nie tylko archiwalnych praktyk pochód z Judoszem stanowi ważny element integracyjny dla mieszkańców. Odwołując się do symboliki religijno-magicznej, a w ostatnim czasie również rozbudowując walory ludyczne czy edukacyjne, przyciąga rokrocznie kolejne pokolenia skoczowian. Ciągłość zwyczaju scala mieszkańców, nie tylko tych uczestniczących w praktykach, ale również tych z przeszłości, jak interpretują to jej zwolennicy. Ma dla nich również wymiar prestiżowy, wzmacniany przez zainteresowanie mediów lokalnych i ogólnopolskich. Nie dziwi zatem fakt, że TMS wyszło z inicjatywą zgłoszenia praktyki pochodu zJudoszem do Krajowej listy niematerialnego dziedzictwa kulturowego UNESCO. W 2018 roku akces skierowano do Narodowego Instytutu Dziedzictwa, który odpowiada za formalne procedowanie wpisu.

Wpis skoczowskiego Judosza na Krajową listę NDK został przedyskutowany na walnych zebraniach TMS i OSP w Skoczowie oraz jednogłośnie zaakceptowany przez uczestników. Obie wskazane wyżej organizacje opracowały plan ochrony i zachowania zwyczajów niezbędny do złożenia wniosku, który ujmuje m.in. działania realizowane od wielu lat. Należą do nich m.in. organizowane przez TMS konkursy plastyczne: Tradycja wodzenia Judosza dla przedszkolaków z terenu gminy Skoczów oraz Czy znasz swoje miasto-gminę? dla dzieci i młodzieży szkół podstawowych (dawniej również gimnazjum).

Niestety wniosek wzbudził negatywne opinie, a osoby odpowiedzialne za procedowanie zwróciły się z pytaniem o możliwość korekty wniosku przed ostatecznym 
przedłożeniem go do Rady ds. niematerialnego dziedzictwa kulturowego, która rekomenduje wpis Ministrowi.

\section{Co skrywa nasz Judosz?}

Fiasko przyjęcia przez NID wniosku o wpis na Krajową listę NDK wprawiło inicjatorów tego przedsięwzięcia w zakłopotanie. W ich opinii bowiem, lokalne dziedzictwo spełnia wymagane w aplikacji kryteria. Jest jedną z niewielu już praktyk kultywowanych nieprzerwanie od pokoleń przez skoczowian. Konflikt, o którym pisałam wcześniej, dodatkowo uwypuklił istotną pozycję zwyczaju dla mieszkańców. Rangę praktyki podnosiła również obecność we współczesnych badaniach etnograficznych (Czerwińska 2009, Studnicki 2009, 2017, Garstka 2013, Garstka, Lysko 2018) oraz popularno-naukowych, gdzie wskazywano jej wyjątkowy charakter. Sugestie, które stały się bezpośrednią przyczyną odrzucenia wniosku, że skoczowski, nasz Judosz jest przejawem antysemityzmu i może podsycać agresywne, wykluczające działania, nie znalazły zrozumienia.

Pod wpływem sugestii płynących z NID-u, zorganizowano spotkanie w celu przeformułowania wniosku, tak by Judosza „ukryć” wśród innych zwyczajów wielkopostnych $^{7}$. Atmosfera w gronie obecnych była niezwykle emocjonalna, łączyła zdziwienie, rozczarowanie, a nawet oburzenie. Kluczowym punktem stało się znalezienie rozwiązania wyjścia z impasu. Jednogłośnie przyjęto stanowisko o „dopasowaniu” wniosku do oczekiwań zewnętrznych interesariuszy reprezentowanych przez NID czy Radę ds. NDK. Innymi słowy, podjęto decyzję o dekonstrukcji lokalnego dziedzictwa (Pochodu z Judoszem) i ponownej jego konstrukcji (Zwyczaje Triduum Paschalnego). W wyniku przyjętych ustaleń powstał nowy wniosek dotyczący skoczowskiego cyklu tradycji wielkopostnych. Wśród praktyk wymieniono: 1) rytualne obmywanie nóg; 2) pochód z Judoszem $\mathrm{w}$ asyście strażaków, mieszkańców Skoczowa i okolicznych miejscowości; 3) przyrządzanie i degustację tatarczówwi oraz 4) odwiedzanie Bożego Grobu pilnowanego przez asystę strażaków z OSP w Skoczowie. Zabieg ten, jak sugerowano depozytariuszom, powinien zwiększyć szanse na pozytywny przebieg procesu certyfikowania dziedzictwa przez stosowne do tego gremia. Nadzieję upatrywano również w możliwości „załatwienia” wpisu poprzez zawodowe koligacje z osobami decyzyjnymi.

Ponowny wniosek złożono w grudniu 2018 roku, ale wprowadzone zmiany nie przyniosły oczekiwanego efektu. $Z$ ustnych przekazów wynika, że Rada ds. NDK postanowiła nie rekomendować tego wpisu i wniosek odrzucić. Niestety depozytariusze nie otrzymali formalnej odpowiedzi, w której sformułowano negatywną argumentację . Pozostają tylko domysły.

7 Konsultacje, które odbyły się 26.11.2018 r., połączono z wykładem prowadzonym przeze mnie pt. Niematerialne dziedzictwo kulturowe a podmiotowość spoteczności lokalnych. Wówczas też poproszono mnie o pomoc w ponownym złożeniu wniosku.

8 Do lipca 2021 roku, kiedy powstawał ten tekst, formalna odpowiedź nie została przesłana wnioskodawcom. 
„Organizowany współcześnie skoczowski Judosz jawi się (...) jako tradycja poddana refleksji, rytuał (widowisko), w którym materializuje się to, co społeczność określa jako swoje dziedzictwo oraz pozytywny obraz przeszłości i z czym pragnie się identyfikować" (Studnicki 2017: 193). Mimo to zaistniała sytuacja zmusiła osoby zaangażowane w przedsięwzięcie do ponownych przemyśleń czy przedefiniowania myślenia o wartości miejscowej tradycji i jej kontunuowaniu w obliczu pojawiających się zarzutów o antysemityzm i utrwalanie figury Judasza - Żyda jako siedliska zła. Zarzuty te są niepokojące, zwłaszcza w kontekście dzieci, które licznie uczestniczą w zwyczaju i dla których kierowane są popularyzujące go aktywności. Naglące stało się rozstrzygnięcie kwestii, czy rzeczywiście słomiana kukła skrywa przejawy antysemityzmu? Czy skoczowianie nie powinni wykazać się większą wrażliwością?

Po raz kolejny sięgnięto do analizy materiałów etnograficznych i historycznych. W literaturze przedmiotu, dla większości katolików Żyd postrzegany jest jako „zabójca Chrystusa”. Lokacja ta warunkowała obraz grupy i ustawiała wzajemne relacje. Nie była ona jednak jednoznacznie negatywna, a raczej ambiwalentna. Obarczała Żydów winą za śmierć Jezusa, ale równocześnie czyniła ich kluczowym świadkiem i uczestnikiem tego misterium. Ich działania zostały zdeterminowane, byli przeklęci, ale zaraz naznaczeni piętnem świętości. Stanowili immanentny i niezbędny element cyklu istnienia świata, odtwarzanego regularnie w praktykach i obrzędach. Dlatego nie można analizować tej praktyki w oderwaniu od kontekstu obrzędowego, jaki występował w kulturze ludowej i roli figury „obcego” w zachowaniu ciągłości cyklu, co podkreśla m.in. Alina Cała, która pisze, że przytoczone opisy przypominają zwyczaj topienia Marzanny:

Tradycja ludowa zaznaczyła w ten sposób nadejścia wiosny, ostateczne przezwyciężenie ciemnych sił, które panowały zimą. Wydaje się, że kukła przedstawiająca Judasza była wtórną, powierzchownie schrystianizowaną formą tego obrzędu. Tłumaczyć zatem należy ją podobnie: pozbycie się tego, co w okresie przejściowym usiłowano obłaskawić. Moce, które miały zainicjować życie, stały się już zbędne. Mogły jedynie zaszkodzić. Dlatego powinno się je wykluczyć. Dokonywano tego za pośrednictwem symbolicznej agresji” (Cała 1987: 131).

W podobnym tonie wypowiada się Małgorzata Kiereś - etnografka i badaczka regionu, mówiąc o wodzeniu Judosza, że „to zwyczaj ludowy, typowy dla czasu, kiedy zima przechodzi w wiosnę. Judosz jest symbolem zła, takim jak Marzanna i w samym obrzędzie nie należy doszukiwać się żadnych dodatkowych podtekstów" . Co jednak ciekawe, jeden z główny propagatorów wiedzy o skoczowskim Judoszu przestrzega, że zwyczaju tego nie należy łączyć z Marzaną, bo oba należą do innych porządków interpretowania świata (Orawski 2008: 2).

9 Wikipedia, 25.07.2021. 
W dyskursie lokalnym związanym z tożsamością miejsca i wyznaczającymi ją regionalnymi kwantyfikatorami, Judosz lokowany jest jako dawny, pogański zwyczaj, odnoszący się do walki dobra ze złem, zimy z wiosną. Konieczność spalenia kukły wiąże się usunięciem zła $z$ granic miasta. Pomagają temu dźwięki klekotek towarzyszące pochodowi (Orawski 2000: 140-141). Rozpowszechniana interpretacja judoszowej praktyki jest swoistą wykładnią, jak należy rozumieć kod symboliczny ulicznej inscenizacji. Balansowanie między symboliką pogańską i chrześcijańską ma niewiele wspólnego z naukowym wywodem, choć wskazywanie na źródła i badania, mają potwierdzać jego poprawność. I w tym dyskursie, nie pojawia się nawet wzmianka o Judoszu - Żydzie, która mogłaby sugerować, że w granicach miasta odbywa się antysemicka nagonka. Rugowanie $z$ dyskursu wątków antysemickich jednoznacznie wskazuje, że współczesne wodzenie Judosza spełnia tu konkretne funkcje: reprodukowania kolektywnej pamięci, rekonstruowania/budowania wspólności grupy, aktywizowania tożsamości na poziomie miejsca.

Prawdopodobnie efektem tych działań jest fakt, iż skoczowski Judosz tylko z rzadka kojarzony jest z Judaszem - Żydem, zdrajcą, przedstawicielem narodu mojżeszowego. W gęstości i wielości konotacji, ładunku semantycznego czy sprzecznych odniesień ukrytych w ambiwalentnej figurze $\dot{Z}$ da (Środa 2020: 157), skoczowianie nie upatrują w nim ustrukturalizowanego zła. Judasz to element, który jest immanentną częścią rzeczywistości doświadczanej, element pasujący i budujący tę rzeczywistość. Kukła nie uosabia konkretnego Żyda, ani też narodu żydowskiego, a kumuluje odtwarzanie cykliczności umierania i odradzania się świata, zaś spalenie jej jest częścią tego rytmu. Istotne znaczenie $\mathrm{w}$ tym procesie odgrywa sama figura pozbawiona jakichkolwiek anatomicznych skojarzeń: ani twarzy, ani wyraźnie wyodrębnionych elementów korpusu czy głowy. Podobieństwo do Judasza podkreślają jedynie srebrniki zawieszone na słomianym chochole i oczywiście kontekst zwyczaju.

Praktyka będąca przedmiotem niniejszych rozważań, jak wspominałam na wstępie, znana była $\mathrm{w}$ innych częściach Polski pod nazwą wieszanie Judasza (Tokarska-Bakir 2004, 73-94). Badacze tematyki żydowskiej wskazują, że stanowiła element zachowań wynikających z koegzystencji zróżnicowanej kulturowej społeczności, niekoniecznie postrzegany jako akt piętnowania Żydów. Alina Cała w badaniach nad Żydami w Polsce, wylicza wiele podobnych działań (Cała 1987). Wynik wspólnej koegzystencji i zderzenia dwóch światów - judaistycznego i chrześcijańskiego wywoływał napięcia na płaszczyźnie nie tylko religijnej. Cała pisze, że figura Żyda i narracja o nim „...miały wydźwięk pejoratywny, ale niekoniecznie były wyrazem ostrych antagonizmów społecznych. Brak szacunku i pogarda dla drugiej grupy mieściły się w ramach pokojowych stosunków" (Cała 1989: 178).

Współczesny pochód Judasza przetrwał m.in. w Pruchniku, gdzie kukłę szyje się z materiału i wypycha słomą, zachowując podobieństwo anatomiczne. Dodatkowo uwypukla się „typowe” żydowskie cechy jak duży nos czy pejsy. Tak spreparowaną postać 
wiesza się na drzewie w centralnym miejscu miasta, w Wielki Piątek, by później wymierzyć jej karę trzydziestu „pałów” za zdradę Jezusa. Joanna Tokarska-Bakir podaje opisy jeszcze $z$ innych miejscowości, głównie z południowej Polski, wskazując, że przed wojną odbywały się one według rozmówców, wszędzie tam, gdzie Żydzi mieszkali (Tokarska-Bakir 2004: 81-83). Obecność tego zwyczaju w innych miejscach podważa unikalność praktyki, niemniej jednak skoczowianie odżegnują się od nich, zwłaszcza po incydencie w 2019 roku, kiedy w relacjach medialnych ukazał się przekaz z Pruchnika, przedstawiony jako akt wandalizmu i przejaw antysemityzmu (Szczęśniak 2019). Incydent ten utwierdził członków TMS w przekonaniu, że losy skoczowskiego wniosku są przesądzone.

W interpretacji zwyczaju skoczowskiego Judosza ważne może być odniesienie do historii stosunków obu, współegzystujących w mieście grup. Stan badań nad tymi relacjami jest niezwykle bogaty i doczekał się licznych opracowań, zarówno dotyczących całego Śląska Cieszyńskiego, jak i gminy i miasta Skoczowa ${ }^{10}$. Żydzi na tym obszarze nie stanowili licznej grupy, w najbardziej dynamicznym etapie rozwoju tej społeczności, w latach 1848-1918, było ich nie więcej niż 10\% ludności ${ }^{11}$. Niemniej jednak tworzyli grupę znaczącą i ważną w rozwoju gospodarczo-społecznym regionu. Od czasów udokumentowanych historycznie, społeczność żydowskich emigrantów docierała tu głównie z Moraw i z tym obszarem utrzymywała najliczniejsze kontakty. Żydzi w Skoczowie, podobnie jak na Śląsku Cieszyńskim, zajmowali się głównie usługami i handlem, arendowaniem alkoholu, dzierżawą pańskich dochodów, a wraz z rozwojem przemysłu również zakładali i prowadzili miejscowe fabryki (m.in. likierów, koców, skór). Z ludnością miejscową utrzymywali sporadyczne kontakty, żyąc własnymi sprawami i w dużym rozdrobnieniu. Sytuacja ta stopniowo ulegała zmianom, wraz z przeobrażeniami gospodarczymi i społecznymi w XIX stuleciu. W konsekwencji środowiska żydowskie, zwłaszcza bogate, emancypowały się i asymilowały, zwłaszcza z kulturą niemiecką. Nie bez znaczenia na te procesy miały rozporządzenia Józefa II z 1787 roku, zmuszające Żydów do posługiwania się językiem niemieckim i zmianę nazwisk na niemieckojęzyczne. Pod koniec XIX wieku tutejsi Żydzi stanowili najbardziej wykształconą grupę narodowościową, specjalizując się w takich zawodach jak lekarze czy prawnicy, co przekładało się również na polityczną i społeczną aktywność. Byt tej grupy zakłóciły zmiany polityczne po 1920 roku. Wprowadzenie granicy państwowej w Cieszynie i rozdzielenie Śląska Cieszyńskiego oznaczało rozłam również dla Żydów. Znaczna część z nich przeniosła się do Czeskiego Cieszyna, gdzie łatwiej było im funkcjonować

${ }^{10}$ Wśród badaczy podejmujących tę problematykę wymienić należy przede wszystkim Janusza Spyrę, którego bogaty dorobek obejmuje liczne teksty w publikacjach zbiorowych i monografiach autorskich. Zob. Spyra 1994, 1997 i inne.

${ }^{11}$ Liczba Żydów w Skoczowie nie była zbyt duża i nawet w najlepszym dla nich okresie, na przełomie XIX i XX wieku nie przekraczała 2,5\% całej populacji (Spyra 1994). 
i utrzymywać kontakty z macierzystym środowiskiem z Moraw. Atmosfera lat 30. XX wieku przyniosła dopiero napięcia społeczne, których wcześniej tutaj nie zaobserwowano. Wystąpienia antyżydowskie odnotowano w Cieszynie czy Bielsku, jednak jak wskazują historycy, miały one charakter społeczny, a nie religijny ${ }^{12}$. Atmosfera zbliżającej się wojny wzmogła migracje. Wielu wyjechało przed 1939 roku, a więc okresem Holokaustu, który zamknął obecność Żydów na tym obszarze. Ci, którzy pozostali, zostali masowo deportowani już na początku 1940 roku. Tylko nielicznym udało się przetrwać. Ich staraniem oraz przy wsparciu lokalnych władz i historyków, na początku lat 90 . XX wieku, przywrócono pamięć o społeczności żydowskiej, która tworzyła to miasto ${ }^{13}$.

Kluczowe dla konstrukcji zwyczaju mają tu zmiany, jakie zaszły w ostatnich trzech dziesięcioleciach, a mianowicie rozszerzenie aspektów więziotwórczego, ludycznego czy edukacyjnego, o których pisałam. Istotne znaczenie ma tu wodzenie, czyli obchodzenie przestrzeni miasta, co potwierdzają słowa Rebecci Solnit: „Gdy idzie się ulicami razem z ludźmi, których łączą te same przekonania, pojawia się rzadka i magiczna szansa na swoistą ludową wspólnotę - coś, co niektórzy być może odnajdują w kościołach, w armiach czy drużynach sportowych...” (Solnit: 2018: 339). Wspólne maszerowanie potwierdza i tworzy solidarność w grupie, łączy równocześnie wnętrze $z$ tym, co zewnętrzne, dotyczy ciała, jego kształtowania, ale i przestrzeni, która podczas chodzenia jest odbierana. Chodzenie to wydeptywanie ścieżek spajających organizm miasta, dla mieszkańców to proces odczuwania przestrzeni własnej, ustanawianie jej jako oswojonej, $\mathrm{w}$ wymiarze społecznym, wspólnotowym ${ }^{14}$. Zwraca na ten fakt również Studnicki:

„W tym momencie powolny, prawie niezauważalny proces nadawania znaczenia przestrzeni miejskiej ulega, na tę krótką chwilę, przyśpieszeniu i intensyfikacji. Przestrzeń miasta jako scena oraz słomiany „Judosz” stają się częścią kodu i środkiem wyrazu, dzięki którym społeczność lokalna ma okazję wspólnie zamanifestować swe przeżycia, przekonania i tożsamość. „Pochód z Judoszem” stwarza okoliczności, w których możliwe jest jednoczesne odtwarzanie, tworzenie i odczytywanie wspólnych kodów i znaczeń, a także pisanie „nowych tekstów kulturowych” oraz umieszczanie ich w przestrzeni miasta” (Studnicki 2009: 231).

Perspektywy synchronicznego i diachronicznego połączenia mieszkańców, którzy są depozytariuszami dziedzictwa pokoleń, akt spajania wspólnoty, są w narracjach o Judoszu

\footnotetext{
${ }^{12} \mathrm{~W}$ relacjach świadka tych wydarzeń, ocalałego z Holokaustu Eliezera Urbacha, wystąpienia antyżydowskie nie miały miejsca w Skoczowie. Koegzystencja obu społeczności układała się zgodnie. Zob. Urbach 1987.

${ }^{13}$ W 1994 roku zorganizowano uroczystości związane z 100. rocznicą powstania gminy żydowskiej w Skoczowie, połączone $\mathrm{z}$ odsłonięciem tablicy i skweru w miejscu zburzonej synagogi, a następnie, w 1997 roku, odrestaurowano cmentarz w pobliskich Wilamowicach.

${ }^{14}$ Tak można tłumaczyć popularność innych procesji, które odbywają się w mieście przy okazji Bożego Ciała czy Święta Trzech Króli.
} 
najczęściej podnoszone. Utrata dawnej tożsamości Skoczowa, opartej o tradycje rzemieślnicze czy przemysłowe, każe miłośnikom miasta ocalać od zapomnienia przetrwałe fragmenty rzeczywistości. W tym kontekście nostalgicznie brzmią słowa inicjatorki wniosku, członkini TMS, Diany Pieczonki-Giec: nam już nic innego nie zostato, tylko nasz Judosz.

\section{Zakończenie}

Wykorzystanie dziedzictwa do budowania tożsamości jawi się jako proces przetwarzania i nieustannej konstrukcji. Stanowi działanie, w którym za punkt wyjścia przyjmuje się fragment przeszłości albo skonkretyzowane struktury, będące tworzywem do kreowania zupełnie nowej konstrukcji. Nie jest to zatem proces jedynie przejmowania i utrwalania formacji historycznej, ale aktywność kulturotwórcza, dla której przeszłość jest pretekstem. Dziedzictwo angażuje teraźniejszą wiarę we wspólnotowość, której przypisuje się wartość, każe odnaleźć i powrócić do zasad plemienności, czyniąc z przeszłości unikatowe dobro, które grupa ma na wyłączność. Historia osadzona w faktach, ustępuje miejsce mitom o pochodzeniu i trwaniu wspólnoty, i tylko jego zachowanie może przynieść prestiż i realizować wspólne cele (Lowenthal 1998).

Oznacza to, że dawne wzory kulturowe są jedynie produktem, a jego potencjał formalny, treściowy lub znaczeniowy może, lecz nie musi, zostać w pełni wykorzystany. Dodatkowo sfera emotywna związana np. z patosem, tęsknotą, nostalgią, towarzysząca zwykle transmisji treści kulturowych wewnątrz danej społeczności, może zostać całkowicie pominięta albo prowokować zupełnie inne wrażenia. Rzeczywistość zamierzchła, nawet przy największym wysiłku, niemożliwa jest do odtworzenia. Przywoływanie form dawnych do teraźniejszości, niesie zawsze znamiona ich fragmentyzacji. Obrazy przeszłości to zatem konstrukt, bardziej lub mniej wiernych jej reprezentacji przywołanych na potrzeby współczesności - symulakrum, jak nazywa je Jean Baudrillard (2005). We współczesnym społeczeństwie dziedzictwo jest bowiem czymś innym, niż było dawniej. Dziś traktujemy dziedzictwo jako dobro świadome - uznajemy jego wartość, ale selektywnie, jak z kolekcji artefaktów, wybieramy z niego to, co uważamy dla nas za ważne lub ciekawe. Korzystamy z tych zbiorów dowolnie i nadajemy im nowy, często własny charakter.

Działania, w których dziedzictwo traktowane jest performatywnie, są obecnie niezwykle popularną formą obcowania z przeszłością. Oprócz wielu walorów edukacyjnych, ludycznych czy rekreacyjnych, pozwalają one legitymizować to, co na co dzień jest trudne do uchwycenia. Myślę tu o treściach kultury, zarówno własnej, rodzimej, jak i innej, której zdefiniowanie pozwala na lepsze poznanie, odczytanie świata. Oczywiście, wydobywanie wiedzy z przeszłości wiąże się niejednokrotnie $\mathrm{z}$ wywoływaniem przemilczanych czy celowo zapominanych wątków, co prowadzi do rozbudzenia konfliktów lub konieczności rewidowania powszechnie przyjętej prawdy o minionych zdarzeniach. Może również, zwłaszcza za pośrednictwem i pod wpływem komercyjnych wymogów rynku, umacniać stereotypowy obraz cech przypisanych depozytariuszom danego dziedzictwa, a także jemu samemu. 


\section{Bibliografia}

Baudrillard J. 2005. Symulakry i symulacja. Tłum. Królak S. Warszawa: Wydawnictwo Sic!

Bauman Z. 1994. Dwa szkice o moralności ponowoczesnej. Warszawa: Instytut Kultury.

Bokszański Z. 1989. Tożsamośc, interakcja, grupa. Tożsamość jednostki w perspektywie teorii socjologicznej. Łódź: Wydawnictwo Uniwersytetu Łódzkiego.

Burszta W. J. 2004. Różnorodność i tożsamość. Antropologia jako kulturowa refleksyjnośc. Poznań: Wydawnictwo Poznańskie.

Broda J. 1972. Rok obrzędowy na Podbeskidziu. Biuletyn Ludoznawczy 1972 (5), 48-50.

Cała A.1987. Wizerunek Żyda w polskiej kulturze ludowej. Warszawa: Wydawnictwo Uniwersytetu Warszawskiego.

Cała A. 1989. Asymilacja Żydów w Królestwie Polskim (1864-1897) : postawy, konflikty, stereotypy. Warszawa: Państwowy Instytut Wydawniczy.

Czerwińska K.2009. Sztuka ludowa na Ślasku Cieszyńskim. Między tradycją a innowacją. Katowice: Wydawnictwo Uniwersytetu Śląskiego.

Ellis C. 2003. The Ethnographic I: A Methodological Novel About Teaching and Doing Autoethnography, Walnut Creek: AltaMira.

Fog Olwing K. 1999. The Burden of Heritage. Claiming a Place for the West Indian Culture. American Ethnologist 26 (2), 370-388.

Garstka R. 2013. Świat obok nas. Katowice: Regionalny Ośrodek Kultury.

Garstka R., Lysko A. 2018. Czas niezwykty. Obrzędowość doroczna na Górnym Ślasku. Katowice: Regionalny Ośrodek Kultury.

Hobsbawm E., Terence R. 2008. Tradycja wynaleziona. Tłum. Godyń F. Godyń P. Kraków: Wydawnictwo Uniwersytetu Jagiellońskiego.

Kajfosz J. 2009. O językowym i kulturowym konstruowaniu tradycji. [W:] J. Adamowski, J. Styka (red.), Tradycja dla wspótczesności. Ciagtośc i zmiana, 2. Tradycja w tekstach kultury. Lublin: Wydawnictwo UMSC, 70-88.

Kwaśniewicz K. 1984. Zwyczaje i obrzędy doroczne. Etnografia Polska, 28 (1), 133-191.

Kwaśniewski K. 1987. Tożsamość kulturowa. [W:] Staszczak Z. (red.) Stownik etnologiczny. Terminy ogólne. Warszawa-Poznań: PWN, 351-352.

Kirshenblatt-Gimblett B. 1998. Destination Culture: Tourism, Museums and Heritage. Berkeley: University of California Press.

Lowenthal D. 1998 The Heritage Crusade and the Spoils of History. Cambrige: University Press.

Lubaś M. 2008 Tradycjonalizacje kultury. O zaletach i ograniczeniach koncepcji „tradycji wymyślonych". [W:] G. Kubica, M. Lubaś (red.), Tworzenie i odtwarzanie kultury. Tradycja jako wymiar zmian spotecznych. Studia z dziedziny antropologii spotecznej. Kraków: Wydawnictwo Uniwersytetu Jagiellońskiego, 33-69.

Lubaś M. 2017. Teoria dziedzictwa kulturowego w naukach społecznych. [W:] A. Chabiera, A. Dąbrowski, A. Fortuna-Marek, A. Kozioł, M. Lubaś, P. Nowak, B. Skaldawski, K. Stępnik Dziedzictwo kulturowe w badaniach. 1. Polacy wobec dziedzictwa. Raport z badań spotecznych. Warszawa-Kraków: Wydawnictwo Uniwersytetu Jagiellońskiego, NID. 17-19. 
Ogrodowska B. 2004. Polskie obrzędy i zwyczaje doroczne. Warszawa: Wydawnictwo Muza.

Orawski R. 2000. Ostatni taki Judosz. Kalendarz Mitośników Skoczowa 2000. Skoczów: Towarzystwo Miłośników Skoczowa,140-141.

Orawski R.2008. Ostatni taki Judosz. Kronika Skoczowuska 22. Skoczów: Towarzystwo Miłośników Skoczowa, s. 1-13.

Pośpiech J. 1987. Zwyczaje i obrzędy doroczne na Ślasku. Opole: Wydawnictwo Instytut Śląski w Opolu.

Solnit R. 2018. Zeww wtóczęgi. Opowieści wędrowne. Tłum. Dzierzgowska A., Królak S. Kraków: Karakter.

Smith L. 2016. „Zwierciadło dziedzictwa”: narcystyczna iluzja czy zwielokrotnione odbicie. Rocznik Antropologii Historii 6 (9), 25-44.

Spyra J. 1994. (red.) W cieniu skoczorwskiej synagogi. Skoczów: Wydano nakładem Komitetu Organizacyjnego 100 rocznicy powstania żydowskiej gminy wyznaniowej w Skoczowie.

Spyra J. 1997. Między Europą a zaściankiem. Żydzi na Śląsku Cieszyńskim na przestrzeni wieków. Studia Etnologiczne i Antropologiczne 1, 58-76.

Studnicki G. 2009. Między tożsamością a atrakcją. Rozważania na marginesie konfliktu wokó1 skoczowskiego „Judosza”. [W:] H. Rusek, A. Drożdż (red.), Tożsamość etniczna i kulturowa Ślaska w procesie przemian. Prace i Materiaty Etnograficzne XXXVI. Wrocław-Cieszyn: Wydawnictwo PTL, 225-242.

Studnicki G. 2017. Skoczowski Judosz. [W:] K. Pieronkiewicz-Pieczko (red.) Ślaskie Prace Etnograficzne: Ślaskie zwyczaje i obrzędy doroczne. Echa przesztości czy żywa tradycja? IV. Katowice: Muzeum Śląskie, 169-195.

Środa M. 2020. Obcy, inny, wykluczony. Kraków: Wydawnictwo Słowo / obraz terytoria.

Szczęśniak A. 2019. Żyd judasz skatowany i spalony w Pruchniku z udziatem dzieci. Skąd ten antysemicki zwyczaj? https://oko.press/zyd-judasz-skatowany-i-spalony-w-pruchniku-z -udzialem-dzieci-skad-ten-antysemicki-zwyczaj, 25.07.2021.

Tokarska-Bakir J. 2004. „Wieszanie Judasza” czyli tematy żydowskie. [W:] J. Tokarska-Bakir Rzeczy mgliste. Eseje i studia. Sejny: Wydawnictwo Pogranicze, 73-94.

Urbach E. 1987. Wyrwany z piekiet. Kraków: Wydawnictwo Sofer.

Wieruszewska M. 1989. Tożsamość kulturowa jako wartość i czynnik konstytutywny społeczności lokalnej. [W:] B. Jałowiecki, B. Sowa, P. Dudkiewicz (red.), Spoteczności lokalne. Teraźniejszość i przysztość. Warszawa: Uniwersytet Warszawski, Universitas, 302-324.

\section{Strony internetowe}

Wikipedia, hasło: Judosz, https://pl.wikipedia.org/wiki/Judosz, 25.07.2021.

Autorka:

Dr hab. Kinga Czerwińska, Prof. UŚ

Instytut Nauk o Kulturze, Uniwersytet Śląski w Katowicach

e-mail: kinga.czerwinska@us.edu.pl 
